\title{
SCIENCE PARADIGM AND PUBLISHING ADEQUACY: WHAT WE WOULD LIKE TO READ IN SCIENTIFIC JOURNALS
}

\author{
Todar Lakhvich \\ International Sakharov Environmental University, Republic of Belarus \\ E-mail: bntu71@gmail.com
}

A few days ago I had an interesting discussion with my master student who recently had entered our university after his graduation as a bachelor from an Arab university. As usual, I gave him few questions for analysis through reviewing scientific Journals and monographs. It was the easiest way to check what his grades in Diploma are worth of and skills in working on a thesis. In all the cases the first chapter of a thesis is to comprise a scientific analysis of the focal problem and therefore it resembles be an introduction to experimental research, in our case in the field of applied Biochemistry.

After years of being a university professor I'm rather sceptical about students' ability to offer at the first attempt a proper scientific review that would meet all the requirements (strangely enough, it's a matter of consideration for some proposals for a scientific Journal). Still I'm an acting professor, appointed as the supervisor for the foreign student and should teach him skills of a scientist. It is just a normal practice. I am used to teach and like to do it, and accept the idea the first attempt barely gets you the final result; anyway, I am there to help to overcome the difficulties (which is an approach in Science education that gives students good experience to enable them to work further on more independently. I am used to correct and edit, to teach and explain, to discuss findings and help to do work in a proper way. That's just all right, that's the process of learning. But in that case, I was absolutely disappointed.

As usual, I expected imperfect, inconsistent, often illogical and chaotic material compiled of large fragments of "borrowed" texts, without proper citation. Instead I saw a single PDF file presenting commercials of the scientific activity pursued by an HT based company, with no citation indeed, though with logotypes of the company set in the page footers and headers. You should have seen the big happy smile upon the face of that foreign student, so proud of presenting the result of his work! Just being a hard nut to crack (I should to put here a smiley in the chat), I began to teach and help. A normal learning process! I tried to explain my student what a literary review means. I told him about the way he should analyse scientific Journals and monographs, about the significance of theoretical backgrounds for experimental research (when entering the university the student emphasized his strong desire to practice contemporary biochemical techniques), the requirements for scientific (still analytical!) publications, the regulations concerning author rights and etc. After a while I got that he barely understood me. While introspecting, I asked whether he carried out any kind of scientific research during his bachelor program abroad, and he replied - NEVER!

So, we are facing the theoretical education only, and no research, analysis, scientific reviewing - just formal grades of formal knowledge. That's just OK (not good though understandable). I would try not to be bored. I'm a supervisor and should teach him to work as a scientist. With the assumption he could learn that. However, after the meeting I kept thinking why I had happened to be disappointed when reading as editor some proposals to a scientific Journal, sometimes angry when scanning some published materials. I asked myself the question what type of scientific articles I'd like to read.

First of all the scientific articles should present new information, giving some additional 
Todar LAKHVICH. Science Paradigm and Publishing Adequacy: What We Would Like to Read in Scientific Journals

PROBLEMS

OF EDUCATION

IN THE $21^{\text {st }}$ CENTURY

Volume 57,2013

6

"sodge. Experimental works apparently give rise to obtain new data. In other words you find "something new" in every case. But "something new" does not necessarily indicate it's interesting and worthy. Context - scientific, educational, practical or simply aesthetical, is of great importance. When presenting their results, even if they are super "fresh" and of great practical value, the authors should clearly understand why it could be interesting for readers, sceptical and cynic scientist-readers in particular! The authors also need to represent their results in such a way the readers will accept the idea the authors want to promote, following the results, developing researches in the field, and finally citing the article. All this does really mean they (scientist-readers and other 'Science policy makers") improve both authors' and Journal rate. The proper strategy, spectacular and adequate title, clear structure, simple language easy to understand and scientific style acceptable for science-readers make your article attractive, useful and thus readable and frequently cited. Great results can be lost because of poor language, bad style and boring inadequate title. And there are many examples of how few words containing good ideas in articles which formally had less scientific data gave rise to new concepts and theories. I want to mention two of them.

The first is the concept of the tetrahedral carbon atom.Van't Hoff who worked in Kekule laboratory apparently had seen in Bonn the famous molecular models, and heard about the tetrahedral carbon. However, he did not acknowledge this debit when he publishes his famous article (Van't Hoff, 1875), where he attributed the optical activity of substances to the existence of spatial isomers, and admitted that the hypothesis of the tetrahedral carbon lay at the basis of his theory. Van't Hoff built some solid tetrahedrons to represent the carbon atoms, stating that they could be combined through their vertex, sides and faces. This representation had two advantages. On the one hand it was a nice model that explained itself splendidly and comprehensively the molecular asymmetry and its consequences on the rotatory power of organic compounds. On the other hand it was an attempt to escape to the critics about the tetrahedral hypothesis of carbon, by picturing the carbon atom as a solid tetrahedron that reminded the asymmetric crystalline structures, already well known at that time (we can mention Pasteur findings on ammonium tartrates enantiomorphic crystals). He did solid models to explain how the optical activity is maintained when the crystals are dissolved in a solvent (it is therefore not a property of the crystals, and has instead a molecular character). It's worthy to say in the context of editorial that the hypothesis of the tetrahedral carbon was circulating from at least the decade, and Kekule and his coworkers had being applied it for several times before Van't Hoff proposed it again in 1875. One can argue, whether Van't Hoff had done something new. The historical perspective gives us a proper answer to a request. Van't Hoff did his the best to popularize the idea: he had published the work and sent his articles to the most eminent chemists of his time. He was able to defend his concepts against the criticism, both practical and theoretical. And he faced it soon. Among such critics was Hermann Kolbe the renowned chemist and the editor of "Journal für Praktische Chemie" (he represented the old guard of "pure synthetic experimentators" struggling against "formal theories" of young generation). Kolbe said disparagingly, alluding to the lower status the university, where Van't Hoff worked: "A certain mister Van't Hoff, who occupies a position at the Veterinarian School of Utrecht, for sure does not like the exact researches. He has considered more pleasant riding Pegasus (apparently borrowed from the Veterinarian School) and to discover in his "Chimie dans l'Espace", how the atoms appear to him to be arranged in space, when he is on the chemical Mt. Parnassus which he has reached by bold flight how are looking the atoms in the universe" (Kolbe, 1877). But in fact the theory of Van't Hoff was firmly established, and the ferocious critics moved by Kolbe in the paper mentioned stirred only hilarity. Just the most prestige Journal for publishing results in the field of Organic chemistry (both synthetic and theoretic) has a title TETRAHEDRON and Van't Hoff won in 1901 the first Nobel Prize in Chemistry.

The second example is a publication made 10 years ago. That episode was dedicated to the aesthetic potential of Science. In 2003 James Tour and Stephanie Chanteau, from the Rice University's Institute for Nanoscale Science and Technology published the provoking article 
in the Journal of Organic Chemistry where they used their knowledge of chemical synthesis to create the NanoPutians (Chanteau and Tour, 2003). To get a little more serious, the idea was actually part of the chemistry education program at the Rice University aimed at introducing Organic chemistry and Nanotechnology to young students. NanoPutians are 2-nm-tall anthropomorphic molecules in monomeric, dimeric, and polymeric form. Put simply, they are people shaped molecules synthesized using a string of chemical reactions. Tour and Chanteau went as far as creating the life cycle of the NanoPutian from NanoKid to NanoProfessional. The article was done on the basis of synthetic research in good scientific traditions, but obviously possessed a great aesthetic and educational potential. The most interesting fact is that it was found nanokids - when taken on specific surface - gave the nanomaterials. That gave rise to commercial use of the invention. Just concept of Beautility reveals a great utility (pragmatic) potential of beautiful things (aesthetic, which can be regarded as moral component, background) (Lakhvich, 2010)

The next point I want to "moralize" is the compliance of the articles and monographs with the requirements of scientific ethics. A few scandals concerning plagiarism in Science took place in the last decade. The most famous was induced by publication in NATURE magazine in 2012; the Romanian prime - minister was accused he had committed copy and paste plagiarism in his $\mathrm{PhD}$ thesis. "Nature has seen documents compiled by an anonymous whistle-blower indicating that more than half of Ponta's 432-page, Romanian-language thesis on the functioning of the International Criminal Court consists of duplicated text. Moreover, the thesis was republished with very minor amendments as a Romanian-language book in 2004), and also forms the basis of a 2010 book on liability in international humanitarian law. A former PhD student of Ponta's, Daniela Coman, is named as co-author of the books." (Schiemeir, 2012). Though the article and events followed by the publication reflected obviously the struggle for political reasons the issue gave rise to more attention to the problem of plagiarism in Science. But even in the cases the authors present their own results we would like to see a profound literary review of the works done before. On the one hand it shows the research was based on real background. On the other - it gives good material for analysis in the discussion and conclusion sections of the article.

Just a bit bored on eve of Christmas and New Year holidays. Want to wish to all the writers and readers their dreams come true and hope to face interesting publications in 2014. And finally, to comply with the requirements of scientific ethics I give the citation to the page which regard our authors what they need to do we like their proposals.

http://www.scientiasocialis.It/pec/files/General_Requirements_PEC.2010.pdf.

\section{References}

Chanteau, S., Tour, J. (2003). Synthesis of Anthropomorphic Molecules. Journal of Organic Chemistry, $68,8750-8766$.

Kolbe, A. W. H., (1877). Journal für Praktische Chemie, XV, 473.

Lakhvich, T. (2010). Science Education: Search for Harmony and Beauty. Journal of Baltic Science Education, 9 (2), 84-86.

Schiemeir, Q. (2012). Romanian Prime Minister accused of plagiarism. Nature, 486, 305.

Vant'Hoff, J. H. (1875). La Chimie dans l'Espace. Rotterdam, 1875.

Received: December 15, 2013

Accepted: December 29, 2013

Todar Lakhvich

PhD., Associate Professor, International Sakharov Environmental University, Minsk, Republic of Belarus.

E-mail: bntu71@gmail.com 